\title{
Preliminary Detection of Antibacterial Activity of Fishpond Water Bacteria against Aquaculture Pathogenic Bacteria
}

\author{
Stella Magdalena1, ${ }^{1}$ indy ${ }^{2}$, Yogiara ${ }^{3}$ \\ ${ }^{1}$ Department of Food Technology, Faculty of Biotechnology, Atma Jaya Catholic University of Indonesia, \\ Jakarta, Indonesia \\ 2 Department of Biotechnology, Faculty of Biotechnology, Atma Jaya Catholic University of Indonesia, Jakarta, \\ Indonesia \\ 3 Department of Magister of Biotechnology, Faculty of Biotechnology, Atma Jaya Catholic University of \\ Indonesia, Jakarta, Indonesia
}

Corresponding author: stella.magdalena@atmajaya.ac.id

\begin{abstract}
Aquaculture is currently experiencing massive loss due to the outbreak of pathogenic bacteria. One of the outbreak causes is the development of pathogenic bacterial resistance to the antibacterial. The problem can be solved using microorganisms that can produce new antibacterial compounds. The purpose of this research was to obtain bacteria from fishpond water that could produce antibacterial compounds. About two out of 81 isolates could produce antibacterial compounds. Those two isolates were obtained from saltwater fishponds in North Jakarta (TS2) and Harapan Island (PHY). All fishpond water was grown in marine broth or Luria broth. Extraction of antibacterial compounds was performed using four types of solvents: chloroform, dichloromethane, ethyl acetate, and methanol. Each of the solvents showed a different result. The extraction can only be successfully performed using chloroform and dichloromethane. Extraction using dichloromethane showed a larger inhibitory clear zone than chloroform. Based on 16S rRNA gene sequencing, PHY isolate was identified as Bacillus sp. and TS2 as Acinetobacter sp. In conclusion, isolate TS2 and PHY, which produced antibacterial compounds, showed potential use as aquaculture probiotics.
\end{abstract}

Keywords: aquaculture; fishpond; antibacterial; probiotic.

\section{Introduction}

Aquaculture is one of the fastest-growing food production sectors in the world for the past decade. Aquaculture production in 1999 increased to more than 42 million tons from 7.4 million tons in 1980. Aquaculture production has reached $7.7 \%$ per year since 1960, the share of cultivated fish from total fish production has increased from $10.6 \%$ in 1960 to $40.2 \%$ in 2014 (Tran et al., 2017). But this achievement has some significant problems, especially with animal diseases. The effect of conditions in aquaculture is overwhelming and also can make an enormous economic loss. Disease outbreaks may be caused by terrible aquatic farming techniques to eliminate pathogens (Prem et al., 2011). The most significant loss of economic value in Penaeus vannamei cultivation in 2010-2016 occurred due to acute hepatopancreatic necrosis caused by Vibrio parahaemolyticus (Shinn et al., 2018).

Terrible aquatic farming to eliminate pathogens may be caused by massively using antimicrobials, like an antibiotic, to control disease and promote growth in 
aquaculture animals. It can cause problems like antimicrobials residues in aquatic animal tissues, modification of bacterial resistance mechanisms, and gastrointestinal microbiota imbalance in marine animals, affecting their health (Carrera et al., 2020; Kumar et al., 2019; Vasiliadou et al., 2018; Francino, 2016).

Those problems, especially resistance development-related issues, can be solved using probiotics, an excellent solution to replacing regular antibiotics to inhibit pathogens and disease control in aquaculture animals. Probiotic microorganisms can produce novel antibacterial with bactericidal or bacteriostatic effect on pathogens in the host's intestine, improve water quality, and make a barrier against the development of opportunistic pathogens (Akhter et al., 2015; Assefa \& Abunna, 2018).

Pathogenic bacteria in aquatic animals are classified as indigenous and nonindigenous. The non-indigenous pathogenic bacteria include Escherichia coli, Clostridium botulinum, Shigella dysenteriae, Staphylococcus aureus, Listeria monocytogenes, and Salmonella sp. In contrast, indigenous pathogenic bacteria include Aeromonas hydrophila and Vibrio vulnificus. Bacteria can become pathogens when organisms are deficient in nutrition and environmental stress, which allow opportunistic bacterial infections. An example of other stressors is low water quality or overstocking. Some pathogenic bacteria species can attack either aquatic animals or humans and maybe without disease symptoms in the marine animals. These human infections caused by pathogenic bacteria transmitted from aquatic animals are quite common and seasonal (Karl et al., 2018).

The research gap is that local probiotics isolated from fishpond, especially bacteria that can produce antibacterial compounds, are still rare. So, this research aimed to obtain bacteria isolated from fishpond water, which can produce antibacterial compounds. Three pathogenic bacteria, including Aeromonas hydrophila ATCC 7966, Vibrio vulnificus ATCC 27562, and Pseudomonas aeruginosa KCTC 1637, were used to determine the antibacterial activity of fishpond water bacteria.

\section{Material and Method}

\subsection{Isolation of Bacteria from Fishpond Water Samples}

Water samples were collected from fishpond within 0-20 $\mathrm{cm}$ depth using a sterile bottle. Water samples were diluted by ten-fold serial dilution into $0.85 \%(\mathrm{w} / \mathrm{v})$ physiological salt and homogenized using a vortex. The diluted water sample was spread on Marine Agar (MA) for the sample from saltwater fishpond (Ren et al., 2018) or Luria Agar (LA) (10g tryptone, $5 \mathrm{~g}$ yeast extract, and $10 \mathrm{~g} \mathrm{NaCl}, 15 \mathrm{~g}$ agar bacteriological, and

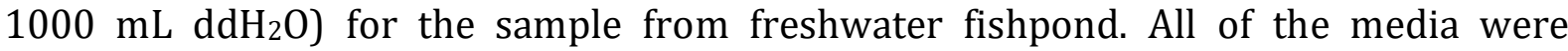
incubated overnight at $28^{\circ} \mathrm{C}$. Each bacteria with different morphology were picked and streaked on respective media. For long-term maintenance, stock solution cultures were stored in $15 \%(\mathrm{v} / \mathrm{v})$ glycerol on tryptic soy broth at $-80^{\circ} \mathrm{C}$. 


\subsection{Extracellular Antibacterial Activity Assay}

Extracellular antibacterial activity was evaluated using the well-diffusion method (Pundir, Rana, Kaur, Kashyap, \& Jain, 2014). P. aeruginosa KCTC 1637 was cultivated in LB at $37^{\circ} \mathrm{C}$; meanwhile, A. hydrophila ATCC 7966 and V. vulnificus ATCC 27562 were cultivated in BHIB at $30^{\circ} \mathrm{C}$. Cultures were incubated overnight. Fishpond water bacteria were grown in Marine Broth (MB) or Luria Broth (LB) (10g tryptone, 5 g yeast extract,

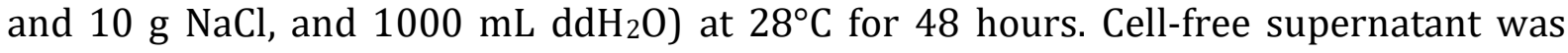
harvested by centrifugation twice $(8,000 \times \mathrm{g}$ for $10 \mathrm{~min})$. Each test bacteria suspension was measured to reach an absorbance of 0.132 at a wavelength of $600 \mathrm{~nm}(0.5$ McFarland). Each $100 \mu \mathrm{L}$ of standardized test bacteria suspension was spread on Mueller Hinton Agar (MHA) by using a sterile cotton bud. A well was made for each section by using a sterile cork borer. Each $20 \mu \mathrm{L}$ of cell-free supernatant was pipetted into each well (Balouiri et al., 2016).

Ampicillin $(10 \mu \mathrm{g} / \mathrm{mL})$ and tetracycline $(30 \mu \mathrm{g} / \mathrm{mL})$ were used as a positive control; meanwhile, MB or LB was used as a negative control. Plates were incubated overnight based on the optimum temperature of each test bacteria. Formed inhibition zone was observed, and the diameter was measured. The forming of the inhibition zone indicates the bacteria isolate can produce extracellular antibacterial compounds.

\subsection{Intracellular Antibacterial Activity Assay}

Intracellular antibacterial activity was evaluated using the cross streak method (Balouiri et al., 2016). The Cross-streak method was started by streaking each bacteria isolate continuously on half of the MHA plate. Streaked plates were incubated overnight at $28^{\circ} \mathrm{C}$. Each test bacteria were inoculated by straight streak at $90^{\circ}$ angles to the bacterial isolate. Inoculated plates were incubated overnight based on the optimum temperature of each test bacteria. A formed inhibition zone was observed after incubation. The forming of the inhibition zone indicates the bacteria isolate can produce intracellular antibacterial compounds.

\subsection{Production of Antibacterial Compound}

PHY and TS2 isolates were grown for 24 hours in $25 \mathrm{~mL} \mathrm{MB}$ or LB at $28^{\circ} \mathrm{C}$. After incubation, each of the grown positive bacterial isolates was measured to reach the 0.5 McFarland standard, which has an absorbance of 0.132 at the wavelength of $600 \mathrm{~nm}$. A total of $80 \mathrm{~mL}$ of inoculum were grown for two days in $400 \mathrm{~mL} \mathrm{MB}$ or LB at $2000 \mathrm{~mL}$ Erlenmeyer Flask using water bath shaker for $120 \mathrm{rpm}$ at $28^{\circ} \mathrm{C}$. After incubation, each of the grown positive bacterial suspensions was moved to the conical tube and centrifuged at 6,000 $\times \mathrm{g}$ for 20 minutes. For positive bacterial in the extracellular antibacterial test, the cell-free supernatant can be tested again using agar well diffusion (Balouiri et al., 2016).

For positive bacteria in the intracellular antibacterial test, the pellet was washed twice and then resuspended using $10 \mathrm{~mL}$ PBS for each step. Each step was centrifuged at 
$10,000 \times \mathrm{g}$ for 10 minutes. Bacterial suspensions were then sonicated for 5 minutes and were centrifuged at $6,000 \times \mathrm{g}$ for 10 minutes. The supernatant can be tested again using agar well diffusion (Balouiri et al., 2016).

\subsection{Extraction of Antibacterial Compound}

The antibacterial compound was extracted using liquid-liquid extraction. The solvent used for the extraction is chloroform, dichloromethane, ethyl acetate, and methanol. The supernatant was mixed with the solvent by a volume ratio of $1: 1(\mathrm{v} / \mathrm{v})$. The mixture was mixed in a separating funnel for 15 minutes and then kept still to separate organic and aqueous phases for 15 minutes prior (Shetty et al., 2014). The organic phase was then collected and separated from the solvent by using a rotary evaporator at $40^{\circ} \mathrm{C}$ with different pressure based on the used solvent (Aboshora et al., 2014). The crude extract was dried using an oven vacuum at $40^{\circ} \mathrm{C}$. The dried crude extract was diluted into PBS and tested again for the antibacterial activity against test bacteria using the well-diffusion method (Aboshora et al., 2014).

\subsection{Molecular identification of PHY and TS2 Isolates}

All of the positive bacteria isolates were molecularly identified by isolating the genome using Wizard ${ }^{\circledR}$ Genomic DNA purification kit (Promega), amplification using PCR, and sequencing. Fragment $16 \mathrm{~S}$ rRNA was amplified using primer sequences $63 \mathrm{~F}$ and 1387R (Marchesi et al., 1998). PCR step was carried out at $94^{\circ} \mathrm{C}$ for $5 \mathrm{~min}$, then followed by 30 cycles of denaturation for $30 \mathrm{sec}$ at $94^{\circ} \mathrm{C}$, annealing for $30 \mathrm{sec}$ at $55^{\circ} \mathrm{C}$, and extension for $1 \mathrm{~min}$ at $72^{\circ} \mathrm{C}$, with a post-extension for $20 \mathrm{~min}$ at $72^{\circ} \mathrm{C}$. PCR product was then visualized by using electrophoresis with $1 \%(\mathrm{w} / \mathrm{v})$ agarose. The gel was stained by using ethidium bromide and destained by using $\mathrm{ddH}_{2} \mathrm{O}$. Visualization of the result was done by Gel Documentation Instrument using UV light. The sequencing of the 16S rRNA gene was performed by $1^{\text {st }}$ BASE, Malaysia. The result was analyzed by using BLAST and compared with the NCBI database.

\section{Results and Discussion}

In this study, 2 out of 81 bacterial isolates (Table 1) showed the ability to produce antibacterial compounds, which are isolated from North Jakarta (TS2) and Harapan Island (PHY). Positive isolates may be difficult to found from freshwater and saltwater fishponds because there are no plenty of nutrients like in marine invertebrates and seaweeds (Veronica et al., 2014). 
Table 1. Total bacteria isolated from saltwater and freshwater fishpond

\begin{tabular}{|c|c|c|c|}
\hline Sources & Location & Organisms & Total Isolates \\
\hline Maritime Higher & \multirow{3}{*}{$\begin{array}{l}\text { North Jakarta, DKI } \\
\text { Jakarta }\end{array}$} & Milkfish (Chanos chanos) and & \multirow[t]{3}{*}{12} \\
\hline Education Institute & & Tilapia (Oreochromis mossambicus) & \\
\hline Fishpond & & & \\
\hline \multirow[t]{2}{*}{ Kepu Village Fishpond } & \multirow{2}{*}{$\begin{array}{l}\text { North Jakarta, DKI } \\
\text { Jakarta }\end{array}$} & Milkfish (Chanos chanos) and & \multirow[t]{2}{*}{18} \\
\hline & & Tilapia (Oreochromis mossambicus) & \\
\hline \multirow[t]{5}{*}{ Harapan Island Fishpond } & \multirow[t]{5}{*}{ Thousand Islands } & Lane Snapper (Lutjanus synagris), & \multirow[t]{5}{*}{17} \\
\hline & & Largescaled Terapon (Terapon & \\
\hline & & theraps), Giant Trevally (Caranx & \\
\hline & & ignobilis), and Big Eye Trevally & \\
\hline & & (Caranx saxfasciatus) & \\
\hline \multirow[t]{2}{*}{ Hawai Fishpond } & \multirow[t]{2}{*}{ Banten, West Java } & Milkfish (Chanos chanos) and & \multirow[t]{2}{*}{17} \\
\hline & & Tilapia (Oreochromis mossambicus) & \\
\hline \multirow[t]{2}{*}{ He Mei Village Fishpond } & Long Dong, & Abalone (Haliotis diversicolor) & \multirow[t]{2}{*}{17} \\
\hline & Taiwan & & \\
\hline
\end{tabular}

The extracellular antibacterial activity test showed that TS2 has antibacterial activity against $A$. hydrophila and $V$. vulnificus (Table 2). There were no isolates with antibacterial activity against $P$. aeruginosa, which may happen because $P$. aeruginosa has an intrinsically high resistance to most antibiotics. This is in line with the previous research (Algammal et al., 2020), which succeeded in isolating $P$. aeruginosa bacteria from the fish culture with multidrug resistance against cefotaxime, amoxicillin, and tetracycline by $70-80 \%$ of the total isolates. Besides that, $P$. aeruginosa can form a biofilm, has a multidrug efflux mechanism, and many structurally unrelated antimicrobial agents (Anupama et al., 2018).

Table 2. Extracellular and intracellular antibacterial activity of fishpond water bacteria against aquaculture pathogenic bacteria

\begin{tabular}{|c|c|c|c|}
\hline \multirow{2}{*}{ Pathogenic } & \multirow{2}{*}{ Isolate Code } & \multicolumn{2}{|c|}{ Clear Zone (mm) } \\
\hline & & Extracellular & Intracellular \\
\hline \multirow[t]{2}{*}{ Aeromonas hydrophila } & TS2 & 4 & - \\
\hline & PHY & 4 & 10 \\
\hline \multirow[t]{2}{*}{ Pseudomonas aeruginosa } & TS2 & - & - \\
\hline & PHY & - & - \\
\hline \multirow[t]{2}{*}{ Vibrio vulnificus } & TS2 & 4 & - \\
\hline & PHY & - & - \\
\hline
\end{tabular}

The percentage of crude extract yield results were varied, between $0.9-2.4 \%(\mathrm{w} / \mathrm{v})$ per $400 \mathrm{~mL}$ medium. All of the antibacterial compounds' extracts were tested again using agar well diffusion methods (Figure 1). After extraction with various types of solvents, the antibacterial activity test, which are chloroform, dichloromethane, ethyl acetate, and methanol, showed that not all of the solvents could bind the antibacterial compounds. Two out of four solvents can extract the antibacterial compounds, which are chloroform and dichloromethane (Table 3). 


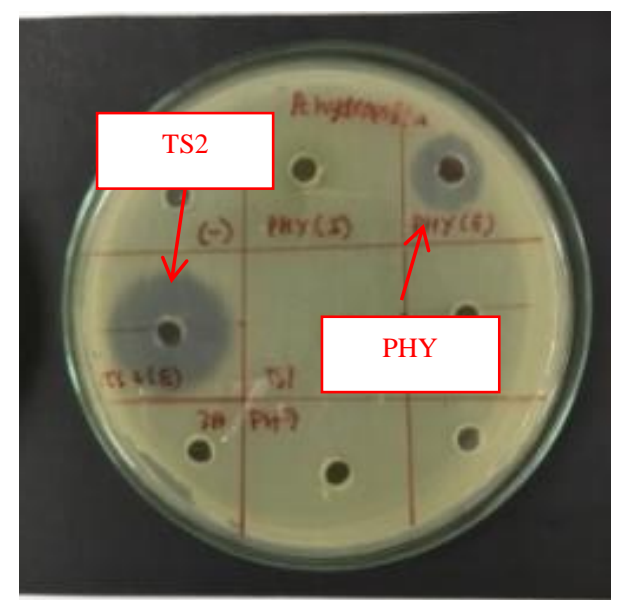

Figure 1. Antibacterial activity of extracellular antibacterial compounds by using dichloromethane extraction against Aeromonas hydrophila

Some extracts of antibacterial compounds have a bigger inhibition zone than before extraction, which is also related to the studies that stated that extracts of antimicrobial compounds would have a bigger inhibition zone than before extraction (Veronica et al., 2014). The better test result of extract extracted by using chloroform against $V$. vulnificus may happen because chloroform can bind antibacterial compounds with anti-Vibrio properties (Preetha et al., 2010).

In Table 3, methanol is not able to extract antibacterial compounds against the three pathogens. This study's result is not in line with the previous study (Gao et al., 2017), which succeeded in extracting anti-Vibrio from supernatant Bacillus pumilus $\mathrm{H} 2$ lyophilized using methanol solvent.

Table 3. Antibacterial activity result after extraction with various type of solvents

\begin{tabular}{|c|c|c|c|c|c|c|c|}
\hline \multirow{2}{*}{ Pathogen } & \multirow{2}{*}{ Bacterial Isolates } & \multirow{2}{*}{$\mathrm{E} / \mathrm{I}^{1}$} & \multicolumn{5}{|c|}{ Clear Zone (mm) } \\
\hline & & & $\mathrm{NE}^{2}$ & $\mathrm{C}^{3}$ & $\mathrm{D}^{4}$ & $\mathrm{EA}^{5}$ & $\mathrm{M}^{6}$ \\
\hline \multirow[t]{3}{*}{ A. hydrophila } & TS2 & E & 4 & 5 & 18 & - & - \\
\hline & PHY & E & 4 & 4 & 10 & - & - \\
\hline & & I & 10 & - & - & - & - \\
\hline \multirow[t]{3}{*}{ P. aeruginosa } & TS2 & E & - & - & - & - & - \\
\hline & PHY & E & - & - & - & - & - \\
\hline & & I & - & - & - & - & - \\
\hline \multirow[t]{3}{*}{ V. vulnificus } & TS2 & E & 4 & 10 & - & - & - \\
\hline & PHY & E & - & - & - & - & - \\
\hline & & I & - & - & - & - & - \\
\hline
\end{tabular}

(1=extracellular or intracellular, $2=$ no extraction, $3=$ chloroform, $4=$ dichloromethane, $5=$ ethyl acetate, $6=$ methanol)

The larger diameter of inhibition was mostly obtained by using dichloromethane than chloroform. There was no result from a positive intracellular antibacterial activity assay. There was also no further new activity other than the previous test before extraction (Table 3). Extraction of the antimicrobial compound depends on the used solvent's polarity (Tan et al., 2020). Polar extracts mostly have a higher antimicrobial activity, which caused the best solvent to extract antimicrobial compounds mostly is methanol. However, 
this present study suggested that no organic solvent showed an effective result in extracting bacterial compounds. There are many factors in finding the optimal solvent, such as target compounds and microorganisms (Pérez et al., 2016). Not all of the antimicrobial compounds are polar; there are also nonpolar antimicrobial compounds like some fatty acids and medium-polar, like alkaloid and flavonoid (Tan et al., 2020). Chloroform and dichloromethane were both nonpolar solvents, so there is no activity using polar solvents like ethyl acetate and methanol. Dichloromethane is also less polar than chloroform, leading to better results because the potential antimicrobial compounds may happen to be nonpolar (Sujatha \& Suresh, 2013).

Molecular identification of positive bacterial isolates was conducted by identifying the 16S rRNA gene. The results showed that PHY was identified as Bacillus sp. and TS2 were identified as Acinetobacter sp. In this study, PHY isolate was obtained from a fishpond filled with Giant Trevally and surrounded by three other marine fish types (Lane Snapper, Large-scaled Terapon, and Big Eye Trevally). A study stated that Bacillus was already successfully isolated from the gut of marine fish and applied as probiotic because of the ability to inhibit pathogens (Thangamani \& Rajendran, 2016). There is still no research about disease treatment using probiotics against pathogens on Giant Trevally because no outbreak of pathogens had occurred.

Bacillus is widely known as a probiotic for aquatic animals and humans, and other animals. Bacillus is currently being developed in a region like Southeast Asia, which the farming of marine animals is very intensive. The beneficial effect of probiotics for the host includes enhancing the immune system, reducing environmental stress, producing exoenzymes, increasing feed digestibility, and producing antimicrobial compounds (Kuebutornye et al., 2019; Olmos et al., 2020). Most commercialized Bacillus probiotics use the production of antimicrobial compound mechanisms, such as bacteriocins and bacteriocin-like inhibitory substances or antibiotics (Soltani et al., 2019). The Genus of Bacillus, such as Bacillus velezensis and Bacillus siamensis, produces vast antimicrobial substances, including polyketide and cyclic lipopeptide; they are capable of inhibiting broad-spectrum aquatic pathogens (Li et al., 2020; Xu et al., 2018; Yi et al., 2018). The genus Bacillus is widely used as a probiotic in aquaculture because of its ability to produce spores to adapt to variations in extreme environmental conditions and limited nutritional resources (Ringø et al., 2020).

In this study, TS2 was isolated from a fishpond filled with Milkfish and Tilapia. A previous study stated that Acinetobacter had already been isolated from both fish, and it is also a common bacteria in the gut of marine fish (Thangamani \& Rajendran, 2016). Acinetobacter KU011TH is known to have antibacterial activity against A. hydrophila, phagocytic activity increases mucosal skin immunity, and is also non-toxic in catfish. Hence, it can be used as a probiotic in aquatic animals (Bunnoy et al., 2019). Acinetobacter sp. that were co-immobilized with Sphingomonas sp., also known to improve water quality and bind pollutants to produce quality crab production (Shao et al., 2020). Besides that, (Liu et al., 2010) study explained that Acinetobacter isolated 
from saltwater fish could degrade poly- $\beta$-hydroxybutyrate (PHB). PHB is the most wellknown polyhydroxyalkanoate and accumulated as carbon and energy storage by many bacteria. $\beta$-hydroxybutyrate can protect aquatic animals from pathogens by two mechanisms that provide energy to the intestinal mucosa, increasing intestinal health, resistance to infections, and decreasing the growth and the virulence of the pathogens.

\section{Conclusion}

There are 2 out of 81 bacterial isolates that can produce antibacterial compounds from saltwater fishponds in North Jakarta (TS2) and Harapan Island (PHY). TS2 can produce extracellular antibacterial compounds against $A$. hydrophila and $V$. vulnificus. PHY can produce both intracellular and extracellular antibacterial compounds against $A$. hydrophila. No antibacterial activity against $P$. aeruginosa from both bacterial isolates. PHY isolate was identified as Bacillus sp. and TS2 identified as Acinetobacter. Extraction of the antibacterial compound can only be successfully performed by using chloroform and dichloromethane. Extraction using dichloromethane had a larger inhibitory diameter than chloroform.

\section{References}

Aboshora, W., Lianfu, Z., Dahir, M., Qingran, M., Qingrui, S., Jing, L., Ammar, A. (2014). Effect of extraction Method and Solvent Power on Polyphenol and Flavonoid Levels in Hyphaene Thebaica L Mart (Arecaceae) (Doum) Fruit, and Its Antioxidant and Antibacterial Activities. Tropical Journal of Pharmaceutical Research, 13(12), 2057-2063. https://doi.org/10.4314/tjpr.v13il2.16

Akhter, N., Wu, B., Memon, A. M., \& Mohsin, M. (2015). Probiotics and Prebiotics Associated with Aquaculture: A review. Fish \& Shellfish Immunology, 45(2), 733741. https://doi.org/10.1016/j.fsi.2015.05.038

Algammal, A. M., Mabrok, M., Sivaramasamy, E., Youssef, F. M., Atwa, M. H., El-kholy, A. W., Hozzein, W. N. (2020). Emerging MDR-Pseudomonas aeruginosa in Fish Commonly Harbor oprL and toxA Virulence Genes and blaTEM, blaCTX-M, and tetA Antibiotic-Resistance Genes. Scientific Reports, 10(1), 15961. https://doi.org/10.1038/s41598-020-72264-4

Anupama, R., Mukherjee, A., \& Babu, S. (2018). Gene-centric Metagenome Analysis Reveals Diversity of Pseudomonas Aeruginosa Biofilm Gene Orthologs in Freshwater Ecosystems. Genomics, 110(2), 89-97. https://doi.org/10.1016/j.ygeno.2017.08.010

Assefa, A., \& Abunna, F. (2018). Maintenance of Fish Health in Aquaculture: Review of Epidemiological Approaches for Prevention and Control of Infectious Disease of Fish. Veterinary Medicine International, 2018, 5432497. https://doi.org/10.1155/2018/5432497 
Balouiri, M., Sadiki, M., \& Ibnsouda, S. K. (2016). Methods for In Vitro Evaluating Antimicrobial Activity: A review. Journal of Pharmaceutical Analysis, 6(2), 71-79. https://doi.org/10.1016/j.jpha.2015.11.005

Bunnoy, A., Na-Nakorn, U., \& Srisapoome, P. (2019). Probiotic Effects of a Novel Strain, Acinetobacter KU011TH, on The Growth Performance, Immune Responses, and Resistance against Aeromonas hydrophila of Bighead Catfish (Clarias macrocephalus Günther, 1864). Microorganisms, 7(12), 613. https://doi.org/10.3390/microorganisms7120613

Carrera, M., Piñeiro, C., \& Martinez, I. (2020). Proteomic Strategies to Evaluate the Impact of Farming Conditions on Food Quality and Safety in Aquaculture $\begin{array}{lllll}\text { Products. } & \text { Foods } & \text { (Basel, } & \text { Switzerland), } & 950 .\end{array}$ https://doi.org/10.3390/foods9081050

Francino, M. P. (2016). Antibiotics and The Human Gut Microbiome: Dysbioses and Accumulation of Resistances. Frontiers in MicrobiologyFrontiers in Microbiology, 6(Article 1543), 1-11. https://doi.org/10.3389/fmicb.2015.01543

Gao, X.-Y., Liu, Y., Miao, L.-L., Li, E.-W., Hou, T.-T., \& Liu, Z.-P. (2017). Mechanism of AntiVibrio Activity of Marine Probiotic Strain Bacillus pumilus H2, and Characterization of The Active Substance. AMB Express, 7(1), 23-23. https://doi.org/10.1186/s13568-017-0323-3

Karl, P. J., Hatch, A. M., Arcidiacono, S. M., Pearce, S. C., Pantoja-Feliciano, I. G., Doherty, L. A., \& Soares, J. W. (2018). Effects of Psychological, Environmental and Physical Stressors on The Gut Microbiota. Frontiers in Microbiology, 9(September), 2013. https://doi.org/10.3389/fmicb.2018.02013

Kuebutornye, F. K. A., Abarike, E. D., \& Lu, Y. (2019). A review on The Application of Bacillus as Probiotics in Aquaculture. Fish \& Shellfish Immunology, 87, 820-828. https://doi.org/10.1016/j.fsi.2019.02.010

Kumar, M., Jaiswal, S., Sodhi, K. K., Shree, P., Singh, D. K., Agrawal, P. K., \& Shukla, P. (2019). Antibiotics Bioremediation: Perspectives on Its Ecotoxicity and Resistance. Environment International, 124(December 2018), 448-461. https://doi.org/10.1016/j.envint.2018.12.065

Li, X., Gao, X., Zhang, S., Jiang, Z., Yang, H., Liu, X., Zhang, X. (2020). Characterization of a Bacillus velezensis with Antibacterial Activity and Inhibitory Effect on Common $\begin{array}{llll}\text { Aquatic Pathogens. } & \text { Aquaculture, 523, }\end{array}$ https://doi.org/10.1016/j.aquaculture.2020.735165

Liu, Y., De Schryver, P., Van Delsen, B., Maignien, L., Boon, N., Sorgeloos, P., Defoirdt, T. (2010). PHB-Degrading Bacteria Isolated from The Gastrointestinal Tract of Aquatic Animals as Protective Actors Against Luminescent Vibriosis. FEMS 
Microbiology Ecology, 74(1), 196-204. https://doi.org/10.1111/j.15746941.2010.00926.x

Marchesi, J. R., Sato, T., Weightman, A. J., Martin, T. A., Fry, J. C., Hiom, S. J., \& Wade, W. G. (1998). Design and Evaluation of Useful Bacterium-Specific PCR Primers That Amplify Genes Coding for Bacterial 16S rRNA. Applied and Environmental Microbiology, 64(2), 795-799. https://doi.org/10.1128/aem.64.2.795-799.1998

Olmos, J., Acosta, M., Mendoza, G., \& Pitones, V. (2020). Bacillus subtilis, an Ideal Probiotic Bacterium to Shrimp and Fish Aquaculture That Increase Feed Digestibility, Prevent Microbial Diseases and Avoid Water Pollution. Archives of Microbiology, 202(3), 427-435. https://doi.org/10.1007/s00203-019-01757-2

Pérez, M. J., Falqué, E., \& Domínguez, H. (2016). Antimicrobial Action Of Compounds from Marine Seaweed. Marine Drugs, 14(3), 52. https://doi.org/10.3390/md14030052

Preetha, R., Jose, S., Prathapan, S., Vijayan, K. K., Jayaprakash, N. S., Philip, R., \& Bright Singh, I. S. (2010). An Inhibitory Compound Produced by Pseudomonas with Effectiveness on Vibrio harveyi. Aquaculture Research, 41(10), 1452-1461. https://doi.org/10.1111/j.1365-2109.2009.02436.x

Prem, A. T., Chellaram, C., Kumaran, S., \& Shantini, C. F. (2011). Screening for AntibioticProducing Marine Bacteria against Fish Pathogens. International Journal of Pharma and Bio Sciences, 2(1), 314-325.

Pundir, R. K., Rana, S., Kaur, A., Kashyap, N., \& Jain, P. (2014). Bioprospecting Potential Of Endophytic Bacteria Isolated from Indigenous Plants of Ambala (Haryana, India). International Journal of Pharmaceutical Science and Research, 5(6), 2309-2319. https://doi.org/10.13040/IJPSR.0975-8232.5(6).2309-19

Ren, Q., Yu, M., Li, Y., Zhang, Y., Shi, X., Wu, Y., Zhang, X.-H. (2018). Flavobacterium ovatum sp. nov., a Marine Bacterium Isolated from an Antarctic Intertidal Sandy Beach. International Journal of Systematic and Evolutionary Microbiology, 68(3), 795-800. https://doi.org/10.1099/ijsem.0.002586

Ringø, E., Van Doan, H., Lee, S. H., Soltani, M., Hoseinifar, S. H., Harikrishnan, R., \& Song, S. K. (2020). Probiotics, Lactic Acid Bacteria and Bacilli: Interesting Supplementation for Aquaculture. Journal of Applied Microbiology, 129(1), 116136. https://doi.org/10.1111/jam.14628

Shao, Y., Zhong, H., Mao, X., \& Zhang, H. (2020). Biochar-immobilized Sphingomonas sp. and Acinetobacter sp. Isolates to Enhance Nutrient Removal: Potential Application in Crab Aquaculture. Aquaculture Environment Interactions, 12, 251262. 
Shetty, P. R., Buddana, S. K., Tatipamula, V. B., Naga, Y. V. V., \& Ahmad, J. (2014). Production of Polypeptide Antibiotic from Streptomyces parvulus and its Antibacterial Activity. Brazilian Journal of Microbiology, 45(1), 303-312. https://doi.org/10.1590/S1517-83822014005000022

Shinn, A. P., Pratoomyot, J., Griffiths, D., Trong, T. Q., Vu, N. T., Jiravanichpaisal, P., \& Briggs, M. (2018). Asian Shrimp Production and The Economic Costs of Disease Asian Fisheries Science, 31S, 29-58. https://doi.org/10.33997/j.afs.2018.31.S1.003

Soltani, M., Ghosh, K., Hoseinifar, S. H., Kumar, V., Lymbery, A. J., Roy, S., \& Ringø, E. (2019). Genus Bacillus, Promising Probiotics in Aquaculture: Aquatic Animal Origin, Bio-Active Components, Bioremediation and Efficacy in Fish and Shellfish. Reviews in Fisheries Science \& Aquaculture, 27(3), 331-379. https://doi.org/10.1080/23308249.2019.1597010

Sujatha, S., \& Suresh, A. (2013). Polar and Nonpolar Solvent Extraction and Pharmacological Evaluation of Four Different Parts from Brassica nigra (Koch.) Plant. Journal of Pharmaceutical and Scientific Innovation, 2, 27-29. https://doi.org/10.7897/22774572.02333

Tan, L. T.-H., Lee, L., \& Goh, B.-H. (2020). Critical Review of Fermentation and Extraction of Anti-Vibrio Compounds from Streptomyces. Progress in Microbes and Molecular Biology, 3(1), a0000051. https://doi.org/10.36877/pmmb.a0000051.

Thangamani, V., \& Rajendran, N. (2016). Total Heterotrophic Bacterial Load in The Gut of Detritus Fishes: A Case Study of Pichavaram Mangrove Environment, Southeast Coast, India. Current World Environment, 11, 778-783. https://doi.org/10.12944/CWE.11.3.12

Tran, N., Rodriguez, U. P., Chan, C. Y., Phillips, M. J., Mohan, C. V., Henriksson, P. J. G., Hall, S. (2017). Indonesian Aquaculture Futures: An Analysis of Fish Supply and Demand in Indonesia to 2030 and Role of Aquaculture Using the AsiaFish Model. Marine Policy, 79(February), 25-32. https://doi.org/10.1016/j.marpol.2017.02.002

Vasiliadou, I. A., Molina, R., Martinez, F., Melero, J. A., Stathopoulou, P. M., \& Tsiamis, G. (2018). Toxicity Assessment of Pharmaceutical Compounds on Mixed Culture from Activated Sludge Using Respirometric Technique: The Role of Microbial Community Structure. Science of the Total Environment, 630(15 july 2018), 809-819. https://doi.org/10.1016/j.scitotenv.2018.02.095

Veronica, V., Lay, B. W., \& Magdalena, S. (2014). Isolation and Characterization of New Antibiotics from Indonesian Coastal Marine Bacteria. Microbiology Indonesia, 8(3), 1. https://doi.org/10.5454/mi.8.3.1 
Xu, B.-H., Ye, Z.-W., Zheng, Q.-W., Wei, T., Lin, J.-F., \& Guo, L.-Q. (2018). Isolation and Characterization of Cyclic Lipopeptides with Broad-Spectrum Antimicrobial Activity from Bacillus siamensis JFL15. 3 Biotech, 8(10), 444. doi:10.1007/s13205-018-1443-4. https://doi.org/10.1007/s13205-018-1443-4.

Yi, Y., Zhang, Z., Zhao, F., Liu, H., Yu, L., Zha, J., \& Wang, G. (2018). Probiotic Potential of Bacillus velezensis JW: Antimicrobial Activity Against Fish Pathogenic Bacteria and Immune Enhancement Effects on Carassius auratus. Fish \& Shellfish Immunology, 78, 322-330. https://doi.org/10.1016/j.fsi.2018.04.055 